\title{
Acts of Citizenship as a Politics of Resistance? Reflections on realizing concrete rights within the Israeli asylum regime \\ Dol:
}

10.1080/13621025.2015.1104291

\section{Document Version}

Accepted author manuscript

Link to publication record in Manchester Research Explorer

Citation for published version (APA):

Müller, T. R. (2016). Acts of Citizenship as a Politics of Resistance? Reflections on realizing concrete rights within the Israeli asylum regime. Citizenship Studies, 20(1), 50-66. https://doi.org/10.1080/13621025.2015.1104291

\section{Published in:}

Citizenship Studies

\section{Citing this paper}

Please note that where the full-text provided on Manchester Research Explorer is the Author Accepted Manuscript or Proof version this may differ from the final Published version. If citing, it is advised that you check and use the publisher's definitive version.

\section{General rights}

Copyright and moral rights for the publications made accessible in the Research Explorer are retained by the authors and/or other copyright owners and it is a condition of accessing publications that users recognise and abide by the legal requirements associated with these rights.

\section{Takedown policy}

If you believe that this document breaches copyright please refer to the University of Manchester's Takedown Procedures [http://man.ac.uk/04Y6Bo] or contact uml.scholarlycommunications@manchester.ac.uk providing relevant details, so we can investigate your claim.

\section{OPEN ACCESS}



Do not quote or cite from this version - please download published article to do so or ask me for a copy
Published in Citizenship Studies, 2016, VOL. 20, NO. 1, 50-66

\section{Acts of Citizenship as a Politics of Resistance? Reflections on realizing concrete rights within the Israeli asylum regime}

\section{Tanja R. Müller}

Acknowledgement: Part of the fieldwork for this study was made possibley funding from the British Academy under its Social Sciences Small Grantoscheme 2010-2011. This support is gratefully acknowledged. I also wish to tha fर all Eritrean refugees as well as those in the various NGOs in Tel Avi $x^{\circ}$ who shared their experiences with me. Lastly thanks are due to two anonous reviewers and the editors for valuable critical engagement.

\section{Abstract}

This paper investigates how Eritreanerefugees in Israel and civil society organisations who engage with refugee issueqcontest the exclusionary politics of asylum in Israel. It presents various acts ofelaims-making initiated by Eritrea refugees themselves or in response to hostilis by others, as well as acts inaugurated by Israeli civil society organisations of behalf of or with refugee populations.

Drawing on the concept of activist acts of citizenship developed by Engin Isin, the $0^{5}$

parer subsequently analyses to what degree those acts have redefined aspects of social

and political membership for Eritrean refugees in Israel. In a further step it shows the limitations of such acts in terms of developing a solidaristic refugee-citizen agenda that profoundly challenges hegemonic public discourse and political debate. The paper concludes by arguing that activist acts of citizenship are best studied in relation 


\section{Do not quote or cite from this version - please download published article to do so or ask me for a copy \\ Published in Citizenship Studies, 2016, VOL. 20, NO. 1, 50-66}

to the transformative power they may have on the various individuals engaging in them, but not as a strategy for a wider politics of resistance, as ultimately nation state politics continue to determine the actual realisation of concrete rights.

Keywords: acts of citizenship; resistance; claims-making; Eritrea; refugees; Israel

We need the Israeli government to understand our problem, thafst is the problem of the refugee, and then if they think they cannethelp us they should let us go somewhere else, we are kept hostage $f$ here, with no rights, with nothing ('Asmeron', male, 26 years dis from Tsorona, Eritrea, interview 6 April 2011 in Tel Aviv).

The arrival of comparatively large newbers of African refugees with legitimate claims for asylum in Israel from 2060 onwards, the first time Israel experienced such a movement by non-Jewislisiefugees, put into sharp focus one of the central problems of the 21st century: the flack of solid footing of universal human rights in actual political space (Long 1 ). Perhaps most famously Hannah Arendt has commented in relation to refugee populations in the 1930 s that the very right to have rights is connected to $0^{2}$ bghig a citizen of a particular state (Arendt 2004). More recently it has been suggested that we witness 'mutations in citizenship', where a global elite can claim quasi universal rights, while others struggle to make rights-based claims or gain access to fundamental material needs. Sites of such 'mutations in citizenship' can be conceptualized as 'spaces of assemblage', in which the realisation of rights or their 


\section{Do not quote or cite from this version - please download published article to do so or ask me for a copy \\ Published in Citizenship Studies, 2016, VOL. 20, NO. 1, 50-66}

denial emerges out of new forms of political mobilisation and associated claims in specific settings (Brun 2001; Ong 2006; Sassen 2008; Tsianos and Karakayali 2010). This paper investigates how such forms of mobilisation that present acts of citizenship are 'constitutive of a localised domain of social existence' (Nyers 2004, p. 204). It further interrogates to what extent such acts can serve as a politics of resistance against sovereign power, focusing in concrete on types of interactions betyen Eritrean refugees, Israeli citizens, civil society organisations, and organs of the state in Tel Aviv.

The term acts of citizenship is based on Isin and Nielsen (2008, expe an understanding of citizenship that moves beyond legal status and its ritualised practices, but focuses on concrete acts. Citizenship thus becomatice that disrupts socialhistorical patterns in that subjects 'constitute the citizens' (ibid., p. 2). As such, acts of citizenship contest the meanntg of citizenship itself. Ultimately, such a relational definition of citizenship fecuses on ways of being with others in the same geographical space (Isin 2008; Villen 2007). Acts of citizenship can thus with equal probability and often sixalt taneously produce strangers, aliens, outcasts or, indeed, citizens (Isin and polsen 2008, p. 11). Focusing on such acts makes it possible to analyse citizeosfip in relation to actual encounters, performances or enactments. In a further it allows to interrogate what makes such encounters agonistic, alienating ogs\&lidaristic (Isin 2008, p. 19).

a

Acts of citizenship and their potential to create new forms of solidarity can usefully be analysed in relation to groups of non-status refugees, who more generally have emerged as key protagonists in global resistance movements (Nyers 2010). 


\section{Do not quote or cite from this version - please download published article to do so or ask me for a copy \\ Published in Citizenship Studies, 2016, VOL. 20, NO. 1, 50-66}

Such activism against exclusionary nation-state politics can be situated along a spectrum between two poles. On one end are demands for the right to social provisions based on the logic of humanitarian compassion, what Isin (2008) calls 'active citizen' engagement. On the other end are overtly political or justice-based claims grounded in global human rights law that ultimately aim to transform the boundaries of citizenship and constitute 'activist citizens' (Isin 2009). But strug for social benefits and political rights are often intertwined. While they maxtiffer in the acts of citizenship they produce and their inherent potential for tonsformative change, active acts can form an important part of activist engagement by non-status populations who, to paraphrase Arendt, lay claim to be those to whom the right to have rights is due.

In relation to non-status refugees and migrants becomes apparent when looking at some examples in the wider literature her work on the sans papiers movent in France, Ticktin (2006) has demonetrated how recourse to humanitarian imperatives over human rights claims - theough a 1998 clause in French law that grants legal residency to those with lobe-threatening illnesses not properly treatable in their home countries - has resulfed in the production of a 'limited humanity' in that recognition of the latter defonds on the former. In contrast, Castañeda (2013) demonstrates in relationcto healthcare provision among unauthorized population groups in Germany $0^{x}$

hge humanitarian and political right struggles can be jointly pursued. At the far end of the spectrum we find multiple acts of core 'activist' citizenship by non-status populations and citizen movements combined in such diverse geographical locations as Australia, Canada, the USA and a variety of European countries. Their sustained engagment in demonstrations, hunger strikes, country-wide marches and other forms 


\section{Do not quote or cite from this version - please download published article to do so or ask me for a copy \\ Published in Citizenship Studies, 2016, VOL. 20, NO. 1, 50-66}

of public campaigns have put into question the 'acceptance of formal citizenship as a precondition for political voice' (Nyers 2010, p. 103; see also McNevin 2006).

In all of the above examples, even where refugee politics has become more restrictive and conceptions of non-status migrants and their entitlements to social welfare are in flux to differing degrees, clear procedures exist for refugee status determination (RSD), and the right to asylum for those who face persecution is recognised find enforceable. This is different from Israel, a country that signed up in principte to the various international refugee conventions, but never experienceg $s^{\circ}$ considerable movements of non-Jewish refugees without citizenship entitlements in practice. The conventions' stipulations have thus not been incorporated domestic law and are not directly enforceable in Israeli courts (Kritzman,28Y0; Ziegler 2011). At the same time, Israel is a classical 'diasporic state' that pows its political legitimacy from a state of refugeeness of Jewish people thrgoghout history. This history is indeed being invoked by Israeli civil society orgąeisations who perform acts of citizenship quasi on behalf of refugee populations, $e^{2}$ a paradigmatic example, the Hotline for Refugees and Migrants had until regently the biblical phrase 'You shall not wrong a stranger or oppress him, for were strangers in the land of Egypt (Exodus 22:20)' as its website banner.

This is the official discourse propagated by the Israeli state and $0^{5}$ moch of the media, where these recent arrivals are not recognised as potential refugees but described as infiltrators - a term that originally referred to armed Palestinian resistance groups who illegally entered Israel from Arab countries (Ziegler 2011). 


\section{Do not quote or cite from this version - please download published article to do so or ask me for a copy \\ Published in Citizenship Studies, 2016, VOL. 20, NO. 1, 50-66}

Contemporary African refugees in Israel thus find themselves at the centre of different types of acts of citizenship (or non-citizenship) - solidaristic, adverse, or hostile, in many of their daily interactions, be it with organs of the state, civil society organisations, people at their workplaces, in their neighbourhoods or in social encounters. This offers the opportunity to study such acts in paradigmatic fashion and interrogate their scope in relation to challenging established notions of citizenship produce new forms of subjectivity that 'do not reproduce the paradoxes of sovereign power' (Nyers 2004, p. 214).

The remainder of this paper will do so in focusing on Eritrean $e^{x}$ fugees, the biggest group of recent arrivals, in Tel Aviv, where the majority regide. It will firstly provide some context about the Eritrean refugees in Tel public claims-making deeds as acts of citizenskippin their various guises and end with some wider conclusions on the potentian for acts of citizenship as a politics of resistance against exclusionary statępolitics. In doing so it complements the academic literature on post-2005 Africantefugee populations in Israel. This has either focused on the legal evolvementcof the Israeli asylum regime (Kritzman and Berman 2009; Kritzman-Amir 2019); on the Israeli state policy response and its implications for refugees (Kalo 2015; Yaron et al. 2013); on the spatial transformation of urban space (Yacobiclis , or on religious discourse and the framing of rights (Sabar 2010). This of

afrele, in contrast, puts activist acts by Eritrean refugees themselves into the centre a

and interrogates sites of mobilisation partly in conjunction with other societal actors from their perspective.

Methodologically, the paper draws on interview and observation data collected during four visits to Tel Aviv, in June 2010, March/April 2011, March/April 2012, and 


\section{Do not quote or cite from this version - please download published article to do so or ask me for a copy \\ Published in Citizenship Studies, 2016, VOL. 20, NO. 1, 50-66}

September 2013. This data consists of 20 in-depth interviews with Eritrean refugees, plus 12 extensive informal conversations. In addition time was spent at social or activist events and in private settings with Eritreans. Selection of Eritrean participants was based on snowball sampling. Key informant interviews were conducted with different members of staff of the main civil society organizations working with refugees, namely the African Refugee Development Centre (ARDC), the fid Organisation for Refugees and Asylum Seekers in Israel (ASSAF), Phyșientans for Human Rights (PHR), the Refugee Law Clinic, the former Hotling for Migrant Workers (renamed Hotline for Refugees and Migrants in Deeember 2013), and Amnesty International (AI). I was also a participant obssiver at various activities conducted by the above organisations, including. fotblic events that centred on engagement with refugee populations. While neasily generalizable, I believe the data give a valid panorama of the ways in then acts of citizenship can foster rights as well as their limitations in a setting gearacterised by exclusionary state policies.

\section{Setting the scene: Eritre}

Israel has from 20 sonwards become an important destination for refugees from the African contioent who entered Israel through its southern border with Egypt/Sinai. ${ }^{2}$ These novements of people only came to a halt with the completion of a sophisticated $0^{2}$ byger fence with state-of-the-art surveillance equipment in 2013 along the Egyptian border. ${ }^{3}$ In the years prior to the border fence completion, the number of African refugees residing in Israel had steadily increased. By September 2013, according to the Population and Immigration Authority, the African refugee population stood at 53,646, among them 35,987 Eritreans and 13,249 Sudanese (see also Tsurkov 2012; 


\section{Do not quote or cite from this version - please download published article to do so or ask me for a copy \\ Published in Citizenship Studies, 2016, VOL. 20, NO. 1, 50-66}

Yaron et al. 2013). The majority live in southern Tel Aviv where some neighbourhoods have been transformed, visible in cafés, bars, shops and hairdressing salons, a fact that on the surface suggests that these populations have become a part of everyday life in the city.

Looking at terminology, legally speaking, Eritreans (and those of other nationalities) arrive in Israel as asylum seekers and becoming a legally recognised refugee would e the outcome of a successful asylum application. But because the self-identifieation as refugee is an important component in the wider claims-making progess, this is the term predominately used throughout this article as interchangeable with asylum seeker.

In order to understand the wider context behind thestrrival of Eritrean refugees in particular, a brief look at political developman within Eritrea is in order. Eritrea became Africa's newest nation state in 1993 after thirty years of armed struggle against Ethiopian rule. A decisive çactor in achieving independence was a strong sense of unity, extending to example of transnationaly strengthening national belonging (Hepner 2009; Pool $e^{2}$

2001). In the first feade after independence this has translated into a high propensity to contribute the development of the country (Iyob 1997; Müller 2004). Partly triggered by renewed conflict with Ethiopia in 1998-2000 that has put on hold the $0^{1}$ ingsementation of a progressive constitution, the Eritrean polity has become highly a

authoritarian, characterized by the crackdown on any form of dissent and potentially indefinite military conscription for those under 40 years of age (Article 19 2012; Human Rights Watch 2009; Müller 2008; Reid 2009). Conscription not only entails curtailment of personal freedoms but can jeopardise any prospect of a life that follows 


\section{Do not quote or cite from this version - please download published article to do so or ask me for a copy \\ Published in Citizenship Studies, 2016, VOL. 20, NO. 1, 50-66}

socially engrained norms, such as earning a viable income and be able to start a family of one's own (Hirt and Adbulkader 2013). The threat of conscription is thus one of the major reasons why people of national service age leave, regardless of whether they have actually been called up.

Eritreans in Tel Aviv and Israel as a whole are predominately young (between 20 and 40 years of age) men and in lesser numbers women from the Christian highlanda ${ }^{2}$ of Eritrea. They have been socialised into the promises of post-liberations politics enshrined in a new constitution. Coming of age they experienceg the denial of constitutional rights, while its obligations have been enforced tefrough a militarized government (Müller 2012). One can in fact describe legung Eritrea is an act of citizenship in itself. Exit is based on state-imposed obligations that deny basic rights commonly associated with citizenshit and voice is not a viable option for resistance as it incurs detention and imprisonment (on exit and voice see Hirschman 1970). Exit can thus be analysed as a a meaningful sense, as voiced $b \mathbf{Q}^{\prime}$ Haile': 'In a country [Israel] that is not our country, a country we do not belois to, I can say what I think about the government, that it is not good, but in ouscountry [Eritrea], the country we gave our blood for, we have no rights, and arohot allowed to ask for our rights [...] I want to have the same feeling [being able to ask for one's rights] tomorrow in my country' ('Haile', male, 30 years ofdrffrom a village near Adi Keih, Eritrea, interview 31 March 2011 in Tel Aviv).

Those dynamics have made Eritrea one of the largest producers of refugees in relation to its population size, and in 2012 Israel was the third largest recipient of Eritrean refugees worldwide (UNHCR 2013). 


\section{Do not quote or cite from this version - please download published article to do so or ask me for a copy \\ Published in Citizenship Studies, 2016, VOL. 20, NO. 1, 50-66}

Once Eritrean (and other) refugees entered Israel through Sinai they gave themselves up to Israeli army patrols. ${ }^{5}$ In most cases they were subsequently taken to detention facilities run by the Israeli Prison Services to be interviewed and processed. Once registered, the refugees were put on buses either to Beer Sheva, the nearest town, or Tel Aviv and released into Israel without further support or guidance and without any of the entitlements the Israeli welfare state offers to its citizens (Furst-Nichols ind Jacobsen 2011; Paley 2011).

When the first refugees arrived the United Nations High Commissiongefor Refugees (UNHCR) office was in charge of refugee status determination bete in 2009 the Israeli government assumed control via the newly established RSSOnit within the Authority of Immigration at the Office of the Interior. Acquistng official refugee status and subsequently citizenship rights is almost impgs though for non-Jews due to the narrow stipulations of Israeli citizenship lant (see Kritzman-Amir 2010, for a detailed discussion). The Israeli asylum regione in terms of legal underpinnings as well as its practice has only been evolving in response to the increasing numbers of refugees from different parts of fica, in an increasingly hostile climate characterised by the notion of the ree as infiltrator (Kalir 2015; Kritzman and Berman 2009; Kritzman-Amơ 2010; Paz 2011; Yaron et al. 2013).

This haciresulted in a state of affairs where refugees are treated differently depending $0^{5}$ og their origin and time of arrival in Israel. The first Eritreans to arrive were given work permits partly in order to fill important gaps in the Israeli labour market, in particular in the construction, agriculture and service sectors, that had come about in the wake of the second intifada (Palestinian uprising) and the deportation of undocumented migrants from Latin American countries and Ghana (Kalir 2010; 


\section{Do not quote or cite from this version - please download published article to do so or ask me for a copy \\ Published in Citizenship Studies, 2016, VOL. 20, NO. 1, 50-66}

Kemp 2004; 2010; Yacobi 2008). ${ }^{6}$ Subsequent arrivals were given a Conditional Release Visa, the 2A5. This visa is based on the UNHCR recommendation from 2008 to grant Eritreans temporary group protection due to the presumption that a majority of Eritreans are likely to satisfy the refugee convention definitions and suffer persecution. The Conditional Release Visa allows refugees to remain in Israel temporarily as long as perilous conditions exist if returned either to Eritrea or to

from where they entered Israel - but they can be deported once those condipons are judged to have changed. ${ }^{7}$ Conditional Release status also delays the gf RSD and thus creates an 'ordered disorder' (Paz 2011) where efugees remain in a state of perpetual insecurity.

The Conditional Release Visa does not allow thestight to work but working is tolerated (ARDC 2011; Ziegler 2011). Since NoQember 2010, however, the sentence 'this is not a working permit' has been exticitly printed on the Conditional Release Visa making it harder for refugeescto find work even though employers have been assured they will not be penalited for employing refugees (ARDC 2011). In parallel, the construction of a pesinanent detention facility with the capacity to host around 3000 refugees, Hat detention centre, was completed in the Negev desert and refugees whoathtil then had lived in Israeli cities started to be summoned to Holot from late 2013 . In addition, various Amendments to the Prevention of Infiltration Act $0^{x}$

hate since 2012 been passed by the government in order to create the legal provisions to

to treat refugees as infiltrators and hold them in detention. ${ }^{8}$ Important aspects of these detention policies have subsequently been struck down by the High Court in cases brought by human rights NGOs. The latest challenge to the government policy to hold infiltrators without trial for 20 months at Holot was heard in early February 2015 - a 


\section{Do not quote or cite from this version - please download published article to do so or ask me for a copy \\ Published in Citizenship Studies, 2016, VOL. 20, NO. 1, 50-66}

decision is still pending. At the time of writing, Holot 'open facility' was the enforced home of 1.940 asylum seekers from Eritrea and Sudan. ${ }^{9}$ Many of those who continue their lives in Israeli cities live in constant fear of being summoned to Holot, thus since 2014 a number of refugees have left under so-called 'voluntary return' procedures instigated by the Immigration Authority that in fact are often based on coercion (see Hotline for Refugees and Migrants 2015 for a detailed discussion). The main rationle behind Israel's detention policy is in fact to induce refugees to return to theirocountry of origin, or a third country in Africa (Human Rights Watch 2014). Af are not a realistic option for the majority of those currently resteling in Israel, they instead engage with the situations they find themselves in various ways that can be analysed as acts of citizenship.

These specific ways of performing citizenshig clude securing social rights mostly through or with the support of various cikis society organisations. With the arrival of $\lambda^{\circ}$

African refugees in Israel some organisations specifically concerned with refugees and asylum seekers, such as thQRefugee Law Clinic (in 2003), ARDC (in 2004) and ASSAF (in 2007) werecteated, in addition to long-established organisations like $e^{l}$

Hotline and PHR broadened their activities to include these new arrivals. Many of their activiodes fall into the sphere of 'active citizen' engagement with the objective to extend some of the social and legal rights that Israeli citizens can expect from the $0^{2}$

ste to refugees. These include for example the provision of health care through a $a^{2}$

refugee clinic and counselling services at PHR, and educational activities, legal advice and a variety of other support services by the wider NGO refugee sector.

Here I focus on activities that aim to constitute 'activist citizens' (Isin 2009), on those acts that aim to move beyond engrained categories of citizens and refugees but are 


\section{Do not quote or cite from this version - please download published article to do so or ask me for a copy \\ Published in Citizenship Studies, 2016, VOL. 20, NO. 1, 50-66}

based on laying claim to quasi-citizen rights by those who are not considered as having the legal right to do so. The following will present a range of such acts and interrogate their scope and limitations in relation to political resistance and the transformation of the joint space Eritrean refugees and Israeli citizens occupy in Tel Aviv. These include acts of claims-making initiated by Eritrean refugees themselves or in response to hostility by others, as well as acts inaugurated by Israeli civil sogety organisations on behalf of or with refugees. The refugee populations whodexecute them in this case study setting do not wish to become legal citizens gf 8 Tel Aviv, but lay claim to be treated as rightful recipients of rights and in Yoing so resist the exclusionary politics of the Israeli state.

\section{Performing political citizenship within aif beyond the Eritrean refugee population}

The first act of citizenship to be presented concerns an attempt by Eritrean refugees to engage in organisational structeres that counter the political vacuum they experience and publicise the fact thathey are rightful refugees and neither 'economic migrants' nor infiltrators. Ond structure was the creation of an Eritrean committee in 2010. The committer formed out of a realisation that it is important to be united and send outa joint message to the Israeli authorities' (meeting with the committee, 30 $0^{1}$

Marth 2011 in Tel Aviv). In order to elect the committee, a public meeting was held at Levinsky Park, an open space opposite the Central Bus Station in southern Tel Aviv that is the main gathering point for refugees. Around 2000 people came to that meeting. This can be read as a public demonstration of the process of creating structures of democratic accountability within a population that thrives to ultimately 


\section{Do not quote or cite from this version - please download published article to do so or ask me for a copy \\ Published in Citizenship Studies, 2016, VOL. 20, NO. 1, 50-66}

live in a democracy and indeed had fled their homeland because of a lack of the right to such gatherings. The five-man-committee was elected for one year and the ARDC provided a physical space for the committee to have an office, conduct meetings and run a surgery to provide advise to Eritreans in need.

The first symbolic political act of the committee was to issue a self-produced but $\curvearrowright$ official looking ID card to very Eritrean refugee that included a photograph and staled 'Eritrean Political Asylum Seeker in Israel'. For the committee this was, 'announce our voice' ('Berhane', male, 33 years old, from Mendefera, Eritrea, interview 1 April 2011 in Tel Aviv) and make a statement about the rights Eritreans were due as refugees. In actively assuming the authority to produce such a quasiofficial document the committee also challenged the stpremacy of the Israeli state to define them as something other than refugees.

For most of those who came to the comminee's surgery, however, this ID card was of little importance but they rather expected concrete help with housing, health issues, or other immediate material probems. As one Eritrean who described himself as unpolitical remarked: 'Mosif of the people who come to this committee have no idea $e^{5}$ what the committewants, they just hope to get some concrete help' ('Neftalem', informal conorsation, 6 April 2011, Levinsky Park). This judgement seems to be confirmet when looking at the participation of the wider Eritrean refugee community $0^{5}$ infoutright political manifestations. The committee from the beginning saw itself also as a force of opposition to the Eritrean government with the ultimate objective to foster political change in Eritrea. One of its members stated, 'we want to take part in the fight against the [Eritrean] regime in an organised manner, and our role as the committee is to enlighten the people about the future of Eritrea, what kind of country 


\section{Do not quote or cite from this version - please download published article to do so or ask me for a copy \\ Published in Citizenship Studies, 2016, VOL. 20, NO. 1, 50-66}

can be built for future generations' ('Michael', 26 years old, from Dekemhare, Eritrea, interview 31 March 2011 in Tel Aviv). One of the first public acts in relation to the latter was the organisation of a demonstration by 'Eritrean political asylum seekers' outside the Eritrean embassy in Tel Aviv to demand political freedom within Eritrea on 11 March 2011. The turnout was a rather disappointing 200 people - a fact that was put down to bad weather by the committee members as it was raining on the but that rather seems to show a disjoint between the performances of political citizenship by a small leadership-elite among the refugees and the bujls of those who are rather concerned with concrete social rights.

In fact, the committee's focus on activist citizenship or visible acts of political claimsmaking is more aligned with some of the civil sgeisty organisations working with refugees and their associates, for whom to ahtinge public discourse within Israeli society with respect to refugees is one pringeे objective. A key member of the Eritrean committee thus was also involvedein a distinct joint project, the creation of the newspaper Refugee Voice that aimed to change attitudes within Israel towards refugees and was introducied by the left leaning newspaper Haaretz (15 April 2011) in an editorial in its Eekend magazine under the title 'let my people stay' (a word play on 'let my people go' referring to biblical history when Moses led the Israeli people back frour Egypt).

ol

Afthe launch event for the Refugee Voice newspaper at a popular nightclub in Tel Aviv on 2 April 2011, some interesting dynamics could be observed. Firstly, similar to the demonstration mentioned above, very few refugees attended the event, which felt more like a party for the Israeli volunteers. Those who did attend stayed among themselves, and when speaking to them told me they preferred to go out to different 


\section{Do not quote or cite from this version - please download published article to do so or ask me for a copy \\ Published in Citizenship Studies, 2016, VOL. 20, NO. 1, 50-66}

bars that were not only cheaper but where they could talk to each other quietly. At some point the newspaper was being presented and the person who gave the speech was an Israeli female volunteer. She started by thanking everybody for their input, as 'I could not have done this without the help of ...' (at which point everybody who contributed an article to the newspaper, refugees and Israelis alike, were mentioned by name). Thus, the newspaper was not presented as a truly joint enterprise in which iwe' (Israelis and refugees alike) came together on an equal footing, but as something that was instigated by Israelis concerned with refugee rights quasi on the $\mathfrak{i}^{\text {P }}$ behalf. In a rather paradoxical way, the claim for universal rights was enacte fashion that indirectly upholds unequal status between frefugees and those who advocate on their behalf. This perception was confirm by some of the Eritreans who did engage with Refugee Voice as an organ tg visibility to their cause. 'Berhe' for example remarked that 'the newspapennts too timid, it does not really address the important issues we face, just gives some stories of suffering' (informal conversation, 7 April 2011, Levinsky Park)., $e^{\ell}$

But looking at Refugeesisoice from the perspective of the majority of Eritrean refugees who in have no desire to be overtly politically engaged but are concerned social entitlements, its humanitarian angle addressed their main concerns Thus even when taking into account the unequal relationship between the $0^{5}$

diferent parties involved in its creation, the newspaper was a magnanimous act of a

activist citizenship inspired by conceptions of solidarity partly with recourse to ancient biblical history.

Meanwhile, neither the Refugee Voice does exist any longer nor does the Eritrean committee, at least in its past form. Some if its more radical members have split and 
Do not quote or cite from this version - please download published article to do so or ask me for a copy

Published in Citizenship Studies, 2016, VOL. 20, NO. 1, 50-66

'transformed the committee away from dealing with refugee rights to become a political committee [focusing only on opposition politics in relation to Eritrea]' ('Michael', informal conversation, 21 March 2012, Tel Aviv). They have become part of the opposition movement Eritrean Youth Solidarity for Change (EYSC) that has sprung up during the Arab spring of 2011 as a global community connected via social media, have moved out of ARDC premises 'as we don't care about refugee rights longer and want nothing to do with these refugee organisations, our aim is topple the Eritrean government' (ibid). While they claim to speak for and ip the Eritrean refugee community in Israel, when discussing these issues with other Eritreans it became quickly clear that this group does ngok for a majority of refugees, many of whom 'hate politics' (informat 60 onversation, 25 March 2012, Eritrean restaurant southern Tel Aviv).

This is not only the case because most Eritreans are too concerned with daily struggles of survival in different wayes, but also because few share the polarised views the group propagates. 'They are self-centred and see everything in black and white, and if you do not agreeswith them they call you a traitor' one of my informants remarked (ibid.). continued to point out that whatever one may think about the Eritrean regine the immediate priority was to avoid creating a lost generation among the mand disillusioned Eritrean youth in Israel, and the latter implied their recognition $0^{1}$ askefugees combined with social rights, first and foremost to education and health.

\section{Demonstrations against the law of the state and other discriminatory encounters}

In December 2013, when the fourth Amendment of the Anti-Infiltration Law that brought about the opening of Holot discussed above was rapidly implemented, 


\section{Do not quote or cite from this version - please download published article to do so or ask me for a copy \\ Published in Citizenship Studies, 2016, VOL. 20, NO. 1, 50-66}

demonstrations by refugees, the various civil society organisations that support them and other concerned Israeli citizens began. Under the slogan 'we are refugees' and the symbol of crossed hands held over ones head handcuffed at the wrist, these demonstrations called for refugee rights and in concrete for freedom from detention without trial. Demonstrations initially included a walk-out-of Holot detention centre, a $ح$ hunger strike, and a walk by refugee groups on Jerusalem. By January 2014 tencof thousands of refugees and their supporters demonstrated and in doing so targated sites of real and symbolic power in Israel, including Rabin Square where theSTel Aviv city government resides, the Knesset (the Israeli parliament), as weld the embassies of the United States and European countries and the offices of UNHCR. In addition refugees held a three day strike that left for example limbo who rely heavily on refugee workers in due course many employers publicly supported the refugees, as did somte other prominent figures within Israeli society. Protests against Israeli detegtion policy have continued at different scales in regular intervals after this imial mass movement. One of the more prominent activities was a march foredom towards the border with Egypt in mid 2014, and $\mathrm{e}^{\mathrm{T}}$

more generally the garious refugee groups engaged in these activities have a wellorganized sociof media presence not only to publicize activities but also to relate to the globar No One is Illegal movement (for a discussion of the latter see Nyers 2010). ot

yolle with limited success in terms of actual achievements of key demands - in few o

cases refugees have been released from detention in Holot when their summons was challenged successfully in the courts - these protests can be described as vocalising acts of citizenship. In addition, the fact that these were mostly joint demonstrations between refugees and Israeli citizens, and were often combined with other forms of 


\section{Do not quote or cite from this version - please download published article to do so or ask me for a copy \\ Published in Citizenship Studies, 2016, VOL. 20, NO. 1, 50-66}

public engagement, such as NGOs staging various support events outside the gates of Holot, or the facilitation of refugee representatives' participation at a Knesset meeting in January 2014, makes them at one level not only activist but also solidaristic acts.

But whether those acts ultimately present a rupture in relation to wider perceptions of refugee entitlements remains in doubt. An interesting fact in relation to the latter were the social protests in Israel that reached their climax in 2011, during which tent cires appeared in various areas of Tel Aviv, most notably on Rothschild Boulevard की in Levinsky Park, where in fact the second largest tent of the Tel Aviy Protests stood for some time. The protests had as their main motto a fight for social justice and against the high cost of living. But even while some of the protesters shared the physical space of Levinsky Park with the refugees wor resided or at least spent their days there, very few actual exchanges took plage?At one point, staff from ASSAF and PHR initiated a joint encounter, but Israejistotest representatives made little attempt to actively include refugee issues in their quest for social justice. In addition, some of the refugee representatives wer in other circumstances would have advanced an activist citizen approachiceared such an approach might backfire in relation to the Israeli protest moveqnent. If they were seen as participants in the wider social protest it might, the argued, enforce the perception of refugees as economic migrants (Jerusalen Post, 9 August 2011). The latter shows the limits to activist citizenship and $0^{5}$

ag htternalisation of some of the exclusionary norms set by Israeli state politics that a

makes refugees actors in their own marginalisation (for a broader discussion of marginalisation-dynamics see McNevin, 2006).

When discussing these issues with two Eritreans from within the 'new' political leadership, they offered the following explanation for the absence of linkages with the 


\section{Do not quote or cite from this version - please download published article to do so or ask me for a copy \\ Published in Citizenship Studies, 2016, VOL. 20, NO. 1, 50-66}

wider social justice movement: During their by then more than three years in Israel, they had studied carefully how 'others' are being treated unequally, even those with on paper full citizenship rights (they referred explicitly to the population of Falasha, black Ethiopian Jews). Thus not only is getting status papers not the solution they aspire to, but they feel they had little in common with or to gain from what Israelis consider to be social justice ('Michael' and 'Abraham', informal conversation 22 March 2012, Levinsky Park).

In addition to demonstrations initiated by refugees and/or on their behaff, anti-refugee demonstrations take place on a regular basis in the neighbourhogd 5 of Tel Aviv where most refugees live. While giving the appearance of being agts of Israeli residents who protest against the influx of refugees and the alleged scrimes' they commit (in actual fact crime figures are much lower among populations than the general average), many of these demonstrations ase organised by right-wing politicians who not only mobilise disgruntled residects but also bus in people from afar, often from some of the disputed settlemens on the West Bank. At times, most prominently in May 2012, such demonstrations have included physical violence against African $\mathrm{e}^{\mathrm{s}}$ residents and the rafsacking of their flats or businesses in southern Tel Aviv. These anti-refuge 4 monstrations can be interpreted as alienating acts of citizenship by those wate want to enforce exclusionary (citizenship) boundaries. At the same time, (.) can trigger a response that publicly transforms refugees into people 'capable of acting like citizens' (Walters 2008, p. 192). During one such demonstration in April 2011 for example, at which demonstrators carried pre-fabricated posters with the slogan 'Expel the 200.000 infiltrators now, if we remain silent, we will become foreigners in our own neighbourhood', an Eritrean business owner came out of his 


\section{Do not quote or cite from this version - please download published article to do so or ask me for a copy \\ Published in Citizenship Studies, 2016, VOL. 20, NO. 1, 50-66}

mobile phone and electronics shop and started arguing with the protesters in fluent Hebrew. He was visibly disturbed by the antagonism and explained at length how his business was in fact providing a much-needed service to the wider neighbourhood. While initially trying to shout him down, the protesters were eventually lost for words and walked on silently, on this occasion cordoned off by Israeli police in order to prevent any direct physical confrontation. While such encounters may do littlalto change perceptions or politics on a larger scale, they are nevertheless acts the disrupt common stereotypes not least because the Eritrean business owner enagfer his right to speak out and challenge the protesters, and in doing so claimedefequal status to voice his opinion as a resident of the same neighbourhood. As Water (2008) reminds us, we should not dismiss such small acts of claims-materg in localised encounters as insufficiently radical as they can play an impoxt role in the way in which refugees constitute themselves as political subjegt Such on the face of it minor acts are especially important for individuageactors in a wider political climate in which $e^{2}$

representatives of almost all poftical parties advocate for the African refugees to not be allowed to live freely 9 srael's major cities.

\section{Symbolic acto of unity and their limits: joint public celebrations}

A further way in which refugees, civil society organisations as well as (some) local or

reflents mingle and visibly occupy public spaces, and in doing so lay claim to a $a^{2}$

right-to-the-city of refugee populations, are public events that celebrate important Jewish holidays. One of the most prominent among those is the yearly refugee-seder organised in Levinsky Park since 2009 under the leadership of the ARDC (an additional refugee-seder was held in front of Holot in 2014). The seder - part of the 


\section{Do not quote or cite from this version - please download published article to do so or ask me for a copy \\ Published in Citizenship Studies, 2016, VOL. 20, NO. 1, 50-66}

Jewish Passover festivities that commemorate the release of Hebrew slaves from bondage in Egypt in ancient times - aims to celebrate freedom and demonstrate solidarity between Jewish people and the refugee community. Its organisers stress important parallels between the narratives of African refugees who have crossed the Egyptian border to seek asylum in Israel because they experienced persecution, and the story of the ancient Jewish exodus from Egypt. Based on my attendance at the refugee-seder on 7 April 2011, I want to offer some observations in relation to its potential as a solidaristic enactment of citizenship that challengeg eontemporary dynamics of exclusion. ${ }^{10}$

The first thing that struck me was the fact that the seder itgelf was being held inside the fenced-off basketball court in Levinsky Park - thusehind 'bars' in a literal sense. As soon as preparations started inside this confleed space, a number of Eritrean and Sudanese refugees gathered outside the contt in order to observe what was going on from a safe distance. Somebody handed out copies of the Refugee Voice newspaper, others handed out flyers wher information on how to enforce the rights of undocumented workers âे claim unpaid wages - the latter became coveted items. $e^{x}$

Joining those outse the basketball court I talked to people, starting with two Eritreans whoofy then had been in Israel for four years. Neither of them had any idea what the ot folt preferred to stay outside. I then spoke to 'Yonas', another Eritrean who had been in Israel for three years, had a good job and had just passed by, 'in general I do not hang out in Levinsky Park', he said. He equally had no intention of joining the seder 'this is like cinema, they [the NGOs] put on a show for themselves, so I rather watch it from the outside' he joked. Once the seder celebration started he was persuaded to 


\section{Do not quote or cite from this version - please download published article to do so or ask me for a copy \\ Published in Citizenship Studies, 2016, VOL. 20, NO. 1, 50-66}

join, even though he did not eat 'the strange food', and we sat together through the various speeches.

The last speech was by one of the chairs of the original five-man-Eritrean-committee discussed earlier. In his speech 'Beraki' said the Eritreans did not want to stay here but return to their country, but as long as that was impossible due to the political situation they needed to be allowed to get on with their lives in Israel. He continuget to say that their major concern was not to get a work permit, but to prepare to to home.

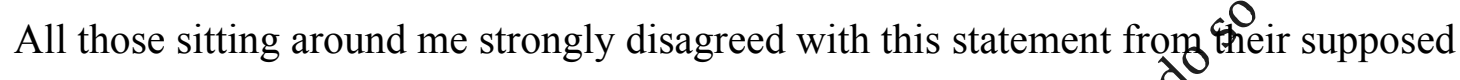
leader - and in fact all of the people spoken to in the course of this research mentioned to get a work permit as their first priority. Adhe same time, they all applauded enthusiastically when 'Beraki' had finishech कोis speech and were proud that 'one of us gave a speech in public and everybody was listening'. 'Beraki' himself later explained to me that "when you givent speech in public you need to be careful not to say things that might threateg local people', and a reference to work permits more generally would enforce, tecente categorisation as 'economic migrants'.

The above observations 8 ffer a number of insights: Firstly, making the public occupation of spate by refugees visible in this way is not something refugees themselves woutd have prioritised - in fact they already occupy the space of Levinsky Park in their everyday encounters as a place to obtain a day's work or simply hang out. $0^{5}$ Sg\&undly, while many are indeed aware of Israeli history and the fact that 'Israel is a country founded by refugees so they should understand our situation' ('Hagos', male, 22 years old, from Segeneity, Eritrea, interview 14 April 2011 in Tel Aviv), the symbolic bond that the conceptualisation behind the refugee-seder aims to create means little to most refugees. Thirdly, it is meaningful to see one of their own 


\section{Do not quote or cite from this version - please download published article to do so or ask me for a copy \\ Published in Citizenship Studies, 2016, VOL. 20, NO. 1, 50-66}

recognised in public for the refugees. But, what he considers to be safe to proclaim as an aspired right is constrained by a kind of self-censorship in relation to the wider public discourse, a fact that mirrors marginalisation dynamics discussed above in relation to the wider Israeli social protest. Lastly, the refugee-seder is born out of the activities of Israeli civil society organisations and individuals who engage in this symbolic act at least as much for their benefit than for the benefit of those support. As such it is an example of what Chouliaraki (2013) calls $\partial \mathrm{a}$ posthumanitarian understanding of solidarity as irony, where charitabje $\mathcal{S}^{\circ}$ acts are not primarily directed at those suffering but conducted for one's $e^{w n}$ fulfilment. This perception has been supported in conversations with staff from AI and PHR. Speaking on condition of anonymity, one staff-member rentrked that no real bottom-up element of engagement with refugees did exist that each NGO would follow their own agenda in relation to what they thought refugees would need (informal conversation, 27 March 2012, $\mathrm{NGO}_{\mathrm{s}}$ effice, Tel Aviv).

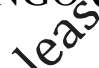

Taken together, while symborc events such as the refugee-seder may from the

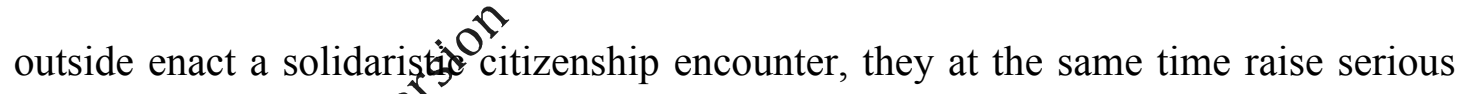
questions about wher such forms of enactment represent the refugee as more than 'the other' ans

ot

\section{Aftivist citizenship and its limits as a politics of resistance}

This paper has discussed different ways in which Eritrean refugees and Israeli citizens engage in acts of citizenship that range from antagonistic to solidaristic. It has shown how refugees commit activist acts of citizenship that aim to transform prevalent norms, not least in proclaiming the right to define themselves as refugees in contrast 


\section{Do not quote or cite from this version - please download published article to do so or ask me for a copy \\ Published in Citizenship Studies, 2016, VOL. 20, NO. 1, 50-66}

to the official designation of infiltrators. In addition refugee populations and civil society movements in conjunction with mobilized citizens literally and metaphorically occupy public spaces in order to challenge state policy. While those acts have to different degrees redefined certain aspects of social and political membership for refugees in Israel, the paper has also shown their limitations in terms of developing a solidaristic refugee-citizen agenda that more profoundly challenges wider public discourse and state politics.

As such, the types of acts of citizenship documented here may lay claim to produce new subjectivities among those who engage in them, and have ar important bearing on self-confidence and aspirations. 'Mussie' who has links the ARDC but has also been involved in setting up various sport and artistic as a small newspaper in Tigrinya, their native 12 inguage, says in this respect: 'I now know what I can do and also want to byntg our people together and do something meaningful for them' (informal cogeversation, 30 March 2012, Café, Tel Aviv). In addition, albeit in a limited wate concrete re-formulations of entitlements have happened on the ground 5 the course of 2013 for example, RSD procedures finally $e^{2}$

started on an indiviat basis as demanded by refugees and most of the organisations supporting thein for a long time - a process that had been delayed by the blank temporat group protection dictum. On the down side, the evaluation of individual $0^{1}$

refests is unreasonably slow and recognition rates are negligible. At the time of a

writing, according to the Population, Immigration and Border Authority, just four asylum seekers from Eritrea and Sudan combined out of 5.573 applications, a rate of 0.07 percent, had been granted refugee status (this compares to an international recognition rate of 84 percent for Eritrean and 56 percent for Sudanese nationals). 


\section{Do not quote or cite from this version - please download published article to do so or ask me for a copy \\ Published in Citizenship Studies, 2016, VOL. 20, NO. 1, 50-66}

In addition, one should not diminish the acts of citizenship committed simply by leading a normal life or running a business as if one was indeed a rightful citizen. It is in fact impossible for refugee businesses to ever be granted full licences, as 'Mekonnen' explains: 'You go to the licensing office with all the papers and they tell you it is better for you to work for somebody else. So you are never secure, they tolerate you but because you do not have an official licence they can close you da any time' ('Mekonnen', male, 30 years old, from Senafe, Eritrea, interview,

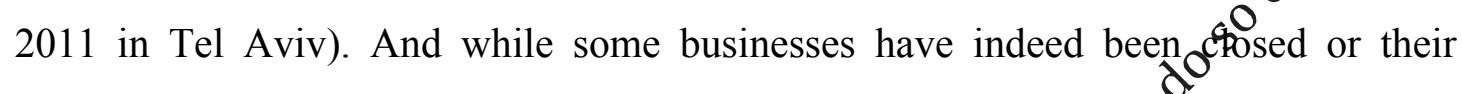
owners closed them for fear of repercussions, the majority contirue to operate as if they had indeed an official licence. Another business oxther says in this respect: 'Many things are complicated in Israel, but we are lixty and have our shops, because after all Israel is one of the democratic countrieQ" ('Haile', male, 30 years old, from Adi Keih, Eritrea, interview 31 March 201 1 . Tel Aviv).

These businesses have quietly transeormed the urban landscape of parts of southern Tel Aviv and are a daily remipder of the contested claims of those who share this space within the city. Nonly does their existence and the fact that the owners pay required taxes chaldenge the representation of refugees as harbingers of violence and crime propagat by some of the anti-refugee demonstrations discussed above. They have also transformed an area that used to be dominated by sex-shops and drug $0^{5}$

dgaling into a different civic space. Xenophobic violence exists and has increased with the growing number of African refugees residing in the area, but one can equally observe numerous daily encounters of conviviality between the different residents of southern Tel Aviv as well as solidaristic relations between refugees and their employers. 'Daniel' says in this respect that while the Israeli government tries to 


\section{Do not quote or cite from this version - please download published article to do so or ask me for a copy \\ Published in Citizenship Studies, 2016, VOL. 20, NO. 1, 50-66}

make society hate the refugees, 'in general most people are good and don't want to discriminate us, and also many employers like us and are not happy with what the government does' ('Daniel', male, 22 years old, from Segeneity, Eritrea, interview 7 April 2011 in Tel Aviv).

Taken together, these everyday encounters represent to different degrees another facet of activist acts of citizenship that form part of a politics of resistance to the Iskeli asylum regime in that they transform 'localised domains of social existence of Nyers, 2004). But the case of Eritrean and other African refugees in Tel Avjisalso cautions against some of the assumptions in the autonomy of migration diterature that regards the act of migration in itself as a form of resistance contemporary forms of economic and social control, an act that opens up possibilities of transformative citizenship (most pronounced perhaps in Hards Negri, 2000). After all, while the examples presented here have demonstrate that formal citizenship or recognition is not a precondition for political vgece, refugees are still being sent to Holot and increasingly coerced into accepling 'voluntary' departure (Booth 2015). The various large-scale demonstrations and other acts of contestation had a very limited effect in $j^{2}$ relation to a transformation of the repressive political regime with regards to refugees in Israel.

This sugidests that acts of citizenship are best studied in relation to the transformative $0^{1}$

pgter they may have on the various individuals engaging in them, but not as an often a

romanticized strategy for a wider politics of resistance, as ultimately nation state politics still very much determine not only the debate but also the actual realisation of concrete rights. 
Do not quote or cite from this version - please download published article to do so or ask me for a copy

Published in Citizenship Studies, 2016, VOL. 20, NO. 1, 50-66

\section{References:}

African Refugee Development Centre (ARDC). 2011. World Refugee Day Report. T Aviv: ARDC.

African Refugee Development Centre and Hotline for Migrant Workers ${ }_{c}$ 2013. 'Do Not Send Us So We Can Become Refugees Again': From 'nationaloof a hostile state' to deportees: South Sudanese in Israel. Tel Aviv: ARDC andxintline.

Arendt, Hannah. 2004 (orig. published 1951). The Orint of Totalitarianism. New York: Schocken Books.

Article 19. 2012. Eritrea: A Nation Silesed. London: Article 19.

Booth, William. 2015. "Israeli gllernment to refugees: Go back to Africa or go to prison." Washington Post. $(04$ May),

http://www.washingţotpost.com/world/middle_east/toughening-its-stance-towardmigrants-israegor

$21 \mathrm{~b} 51 \mathrm{bb} 3 \mathrm{e}$ story.html, accessed 17 May 2015.

ot

Boum, Catherine. 2001. "Reterritorializing the relationship between people and place a

in refugee studies." Geografiska Annaler 83 (B (1)):15-25.

Castañeda, Heide. 2013. "Medical aid as protest: acts of citizenship for unauthorized im/migrants and refugees." Citizenship Studies 17 (2):227-40. 
Do not quote or cite from this version - please download published article to do so or ask me for a copy

Published in Citizenship Studies, 2016, VOL. 20, NO. 1, 50-66

Chouliaraki, Lilie. 2013. The Ironic Spectator: Solidarity in the Age of Posthumanitarianism. Cambridge: Polity Press.

Furst-Nichols, Rebecca and Karen Jacobsen. 2011. African Migration to Israel. Debt, Employment and Remittances. Boston, MA: Tufts University, Feinstein International Centre.

Hardt, Michael, and Antonio Negri. 2000. Empire. Cambridge, MA: Harvard University Press.

Hepner, Tricia R. 2009. "Seeking Asylum in a Transnational Sge Refugees and Struggles for Autonomy and Human Rights " Biopolitics, Militarism and Development. Eritrea in the Twenty-First Centus'edited by David O'Kane and Tricia Redeker Hepner, 115-33. New York: BexgRahn Books.

Hirschman, Alfred O. 1970. Exit, Voigeotnd Loyalty. Responses to Decline in Firms, Organisations, and States. Camberage, MA: Harvard University Press.

Hirt, Nicole and Abdulkander'Saleh Mohammad. 2013. "'Dreams don't come true in Eritrea': anomie and family disintegration due to the structural militarisation of society." Jourg of Modern African Studies 51 (1):139-68.

Hotline 9 ror Refugees and Migrants. 2015. Where there is No Free Will: Israel's “\&luntary Return” procedure for asylum-seekers. Tel Aviv: Hotline for Refugees a

and Migrants.

Human Rights Watch. 2009. Service for Life. State Repression and Indefinite Conscription in Eritrea. New York: Human Rights Watch. 
Do not quote or cite from this version - please download published article to do so or ask me for a copy

Published in Citizenship Studies, 2016, VOL. 20, NO. 1, 50-66

_. 2014. "Make Their Lives Miserable". Israel's Coercion of Eritrean and

Sudanese Asylum Seekers to Leave Israel. New York: Human Rights Watch.

Isin, Engin F. 2008. "Theorizing Acts of Citizenship." In Acts of Citizenship, edited by Engin F. Isin and Greg Nielsen,15-43. London: Zed Books.

_.2009. "Citizenship in flux: The figure of the activist citizen." Subjectivity

29:367-88.

Isin, Engin F., and Greg Nielsen (eds). 2008. Acts of Citizenship. Lorbn: Zed Books.

Iyob, Ruth 1997. "The Eritrean Experiment: a Cautious Pragatism?" Journal of Modern African Studies 35 (4):647-73.

Kalir, Barak. 2010. Latino Migrants in the Jerosth State. Undocumented Lives in Israel. Bloomington, Indiana: Indiana Utversity Press.

- 2015. "The Jewish Stapof Anxiety: Between Moral Obligation and Fearism in the Treatment of Africis Asylum Seekers in Israel." Journal of Ethnic and Migration Studies 4\$(4): 580-598.

Kemp, Adrr ha. 2004. "Labour migration and racialisation: labour market $\mathrm{c}^{\mathrm{C}}$

mechôisms and labour migration control policies in Israel." Social Identities 10

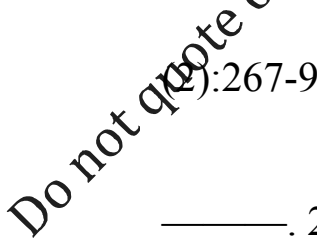

. 2010. "Reforming Policies on Foreign Workers in Israel." OECD Social,

Employment and Migration Working Papers, 41 pages. Paris: OECD. 
Do not quote or cite from this version - please download published article to do so or ask me for a copy

Published in Citizenship Studies, 2016, VOL. 20, NO. 1, 50-66

Kritzman, Tally, and Yonatan Berman. 2009. "Responsibility Sharing and the Rights of Refugees: The Case of Israel." Express $O, 25$ pages.

http://works.bepress.com/tally_kritzman_amir/, accessed 16 June 2010, copy on file.

Kritzman-Amir, Tally. 2010. "'Otherness" as the Underlying Principle in Israel's Asylum Regime." Israel Law Review 42 (3):603-27.

Long, Katy. 2011. "Refugees, repatriation and liberal citizenship." History of

European Ideas 37:232-41.

McNevin, A. 2006. "Political belonging in a neoliberal era: Thestruggle of the sanspapiers." Citizenship Studies 10 (2):135-51.

Müller, Tanja. 2004. "'Now I am Free" - Educati\&n and Human Resource Development in Eritrea: Contradictions in Lives of Eritrean Women in Higher Education." COMPARE 34 (2):215-20.

do

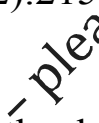

_.2008. "Bare life and the developmental state: the militarization of higher education in Eritrea." 8 urnal of Modern African Studies 46 (1):111-31.

-20120\% From rebel governance to state consolidation - Dynamics of loyalty and the securitisation of the state in Eritrea." Geoforum, 43 793-803.

aryers, Peter. 2004. "Introduction: What's left of citizenship?" Citizenship Studies 8 (3):203-15.

—. 2010. "No One is Illegal Between City and Nation." Studies in Social Justice 4 (2):127-43. 
Do not quote or cite from this version - please download published article to do so or ask me for a copy

Published in Citizenship Studies, 2016, VOL. 20, NO. 1, 50-66

Ong, Aihwa. 2006. "Mutations in Citizenship." Theory, Culture \& Society 23 (23):499-531.

Paley, Maya. 2011. Surviving in Limbo. Lived Experiences among Sudanese and Eritrean Asylum Seekers in Israel. Tel Aviv: Aid Organisation for Refugees and Asylum Seekers in Israel.

Paz, Yonathan. 2011. "Ordered disorder: African asylum seekers in Israel and 0 discursive challenges to an emerging refugee regime." UNHCR Policy and Evaluation Series, New Issues in Refugee Research Paper Ne 205:21.

Physicians for Human Rights. 2010. Hostages, Torture, aid Rape in the Sinai Desert: A PHR-Israel update about recently arriving asyll seekers. Tel Aviv: PHR

Pool, D. 2001. From Guerrillas to Govergatent. The Eritrean People's Liberation Front. Oxford: James Currey.

Reid, Richard. 2009. "The Rolitics of Silence: Interpreting Stasis in Contemporary Eritrea." Review of Afterean Political Economy 36 (120):209-21.

Sabar, Galia 8010 . "Israel and the 'Holy Land': The Religio-Political Discourse of Rights a a thong African Migrant Labourers and African Asylum Seekers, 1990-2008." A rcan Diasporas 3:43-76.

a

Sassen, Saskia. 2008. "Neither global nor national: novel assemblages of territory, authority and rights." Ethics \& Global Politics 1:61-79.

Ticktin, Miriam. 2006. "Where ethics and politics meet: The violence of 
Do not quote or cite from this version - please download published article to do so or ask me for a copy

Published in Citizenship Studies, 2016, VOL. 20, NO. 1, 50-66

humanitarianism in France." American Ethnologist 33 (1):33-49.

Tsianos, Vassilis, and Serhat Karakayali. 2010. "Transnational Migration and the

Emergence of the European Border Regime: An Ethnographic Analysis." European Journal of Social Theory 13:373-87.

Tsurkov, Elisabeth. 2012. "Cancer in Our Body". On Racial Incitement,

Discrimination and Hate Crimes against African Asylum Seekers in Israel. Atviv:

Hotline for Migrant Workers.

United Nations Refugee Agency (UNHCR). 2013. Asylum Treets 2012. Levels and

Trends in Industrialized Countries. Geneva: UNHCR.

Van Reisen, Mirjam, Meron Estefenos, and Coniy Rijken. 2012. Human Trafficking in Sinai: Refugees between Life and Deatjo:Brussels/Tilburg: Europe External Policy Advisors.

Walters, William. 2008. "As of Demonstration: Mapping the Territory of (Non-

)Citizenship." In Acts \&广"Citizenship, edited by Engin F. Isin and Greg Nielsen,182-

206. London: Za

Willen, 今̈arah S. 2007. "Toward a Critical Phenomenology of "Illegality": State $0^{2}$

Power, Criminalisation, and Abjectivity among Undocumented Migrant Workers in

Tel Aviv, Israel." International Migration 45 (3):8-38.

Yacobi, Haim. 2008. "Irregular Migration to Israel: The Sociopolitical Perspective."

European University Institute, CARIM (Cooperation project on the social integration 


\section{Do not quote or cite from this version - please download published article to do so or ask me for a copy \\ Published in Citizenship Studies, 2016, VOL. 20, NO. 1, 50-66}

of immigrants, migration and the movement of persons) Analytic and Synthetic Notes, Irregular Migration Series 2008/63:9.

—. 2011. “'Let Me Go to the City': African Asylum Seekers, Racialization and the Politics of Space in Israel.” Journal of Refugee Studies 24 (1): 47-68.

Yaron, Hadas, Nurit Hashimshony-Yaffe, and John Campbell. 2013. "'Infiltrators

Refugees? An Analysis of Israel's Policy Towards African Asylum-Seekers

International Migration 51 (4):144-57.

Ziegler, Reuven. 2011. "A Matter of Definition: On 'Infiltratoxec and 'Asylum

Seekers' in Israel."

http://www.idi.org.il/sites/english/ResearchAndPratams/ConsititionalLaw/Pages/A MatterofDefinition.aspx28 February 2012, føy on file.

\section{ENDNOTES}

${ }^{1}$ The term was Yegally defined in the 1954 Prevention of Infiltration Act that describes infiltrator as a person who entered Israel from Lebanon, Egypt, Syria, SaudótArabia, Jordan, Iraq or Yemen, and is a resident or a visitor thereof. An $\mathrm{o}^{\mathrm{e}}$

Ninfiltrator can face a five-year prison sentence for crossing the border illegally (Kalir 2015; Ziegler 2011).

${ }^{2}$ This has not been the first time Africans or other foreign nationals came to Israel. In the early 1990s labour migrants were purposefully recruited to replace Palestinian workers from the occupied territories in the aftermath of the first intifada (uprising). 


\section{Do not quote or cite from this version - please download published article to do so or ask me for a copy \\ Published in Citizenship Studies, 2016, VOL. 20, NO. 1, 50-66}

In their wake, Israel also attracted undocumented workers and refugees from various continents. The majority lived in similar parts of Tel Aviv as the contemporary refugee population, whose municipality adopted a welcoming approach in relation to welfare and health provision. From 2002 onwards the Israeli government started to adopt an aggressive policy of deportation and by 2005 most foreign workers hgot indeed been deported or had left voluntarily (Kemp 2004; Yacobi 2008).

${ }^{3}$ The security fence covers the length of the 240 kilometres border betwegh Israel and Egypt and once completed had an immediate effect on the nymiter of refugees entering the country: While in the first half of 2012 reponedly 9,570 citizens of various African countries entered Israel illegally, this number had been reduced to 34 in the first six months of 2013 and has since then stobd at almost zero (Arutz Sheva, 2 July 2013, http://www.israelnationalnews.com/Ngos/News.aspx/169521\#.UeXqBUB15DQ, accessed 25 March 2014).

${ }^{4}$ All names of Eritrean rearch participants have been changed for reasons of confidentiality.

${ }^{5}$ In addition, refugees of different nationalities began to be abducted and trafficked through Sigat by Bedouin groups, and incidents of rape, blackmail and even organ harvesting have been documented (see Physicians for Human Rights 2010; Van $\mathrm{o}^{\mathrm{e}}$

2reisen et al. 2012). It is beyond this paper with its focus on Eritreans who live in Israel to discuss those dynamics in more detail.

${ }^{6}$ By mid 2011, 496 refugees from Darfur had received temporary resident permits (A5 visas), while 2000 Eritreans who had entered before 2009 had received B1 visas which permit holders to legally work in Israel (Paley 2011). Refugees from Darfur are 


\section{Do not quote or cite from this version - please download published article to do so or ask me for a copy \\ Published in Citizenship Studies, 2016, VOL. 20, NO. 1, 50-66}

regarded as most deserving as the discourse around Darfur centres on the language of genocide, a concept that has a lot of resonance among Israeli politicians and the general public alike.

${ }^{7}$ This has happened with respect to refugees from South Sudan who were entitled to Conditional Release Visas in the past. In early 2012 the Israeli government announce ${ }^{5}$ it would detain and deport any South-Sudanese who did not leave voluntarily becuse with independent statehood South Sudan was now considered a safe countoy to return to. This stipulation has been partly successfully challenged by thd Refugee Rights Clinic (Anat Ben-Dor, email communication 10 February $2 a d e^{e}$ ). Nevertheless many refugees from South Sudan have returned 'quasi voluntally', and cases of a 'forced' return have also been reported (see African Refuggobevelopment Centre and Hotline for Migrant Workers 2013).

${ }^{8}$ These are amendments to the originglofect from 1954 aimed at Arab enemies of the state of Israel (see endnote 1 abeee). The first amendment from January 2012 defined any person who enters Isra illegally as an infiltrator, including prospective asylum seekers. The government argued this would authorise detention for up to three years once a deportatiply order has been issued. The High Court struck this detention policy down. This subsequently resulted in various other amendments passed by the goveonent that either shortened the time of detention or made the distinction $x^{e}$

oetween prison and an 'open facility' like Holot, all of which were either rejected or challenged by the High Court (for a detailed discussion see Hotline for Refugees and Migrants 2015).

${ }^{9}$ Holot is characterised as an 'open' facility because those brought there can in theory leave, but they need to check in once a day (down from three times previously) and 
Do not quote or cite from this version - please download published article to do so or ask me for a copy

Published in Citizenship Studies, 2016, VOL. 20, NO. 1, 50-66

stay there at night, otherwise they face transferral to Shaorin prison. But Holot's remote location in the Negev desert makes it quasi impossible to leave and its occupants suffer from severe boredom and any lack of prospects for the future.

${ }^{10}$ The following is based on my fieldwork diary, entry 7 April 2011. 